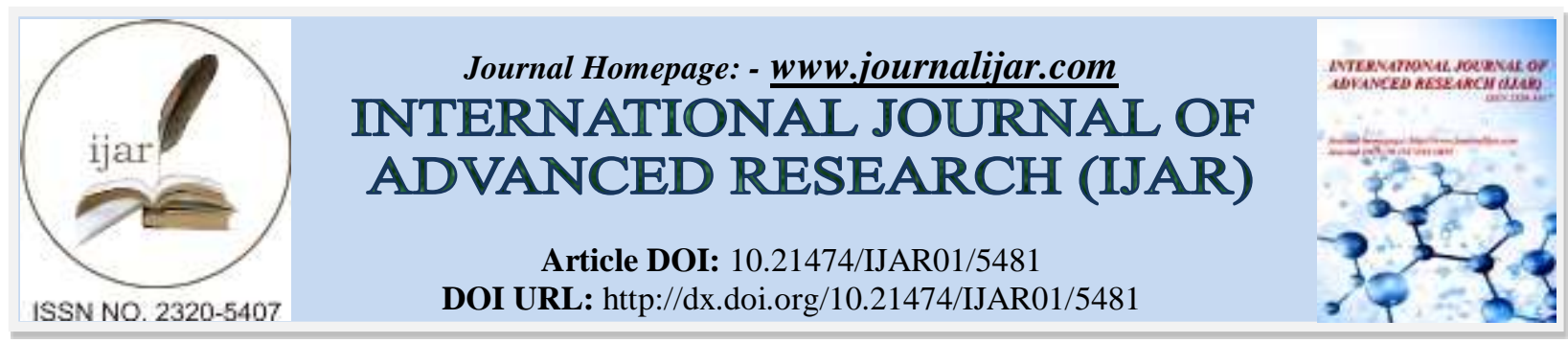

RESEARCH ARTICLE

\title{
ABSORPTIVE CAPACITIES AND INTELLECTUAL CAPITAL IN GRADUATED ENTERPRISES FROM A BUSINESS INCUBATOR IN THE NORTH OF MEXICO.
}

\author{
Marisol Rodríguez Borbón, Cecilia Lorena Velarde Flores, Sacnicté Valdez del Río, Valeria Carolina León \\ Ramírez and Marco Alberto Núñez Ramírez. \\ Instituto Tecnológico de Sonora. Sonora, México.
}

\section{Manuscript Info}

Manuscript History

Received: 20 July 2017

Final Accepted: 22 August 2017

Published: September 2017

Key words:-

Absorptive capacities, intellectual capital, business incubator.

\begin{abstract}
Today, the intangible assets have become important resources in organizations, due to they generate value and raise the life expectancy of companies. However, there is no analysis related to the generation of these assets, especially those that involve the development of knowledge in newly created companies. It is for this reason that the objective of this research is to identify the relationship between the absorption capacities and the intellectual capital, as well as knowing the influence level of these capacities on the intellectual capital development (human, structural and relational capital). In order to elaborate this study, it was applied a survey to 100 graduated companies from the business incubator in the Technological Institute of Sonora, in Ciudad Obregon, Sonora, Mexico. A quantitative analysis was applied using Pearson correlation and multiple regression. It was identified the existence of a relationship and a partial influence among the studied variables, although a positive relationship was found, not in all cases the link was significant.
\end{abstract}

Copy Right, IJAR, 2017,. All rights reserved.

\section{Introduction:-}

The economic structure has undergone major changes from the arrival of the knowledge society, directly affecting companies (Drucker, 1969; Machlup, 1962). It is from this event, intangible assets have become a starting point for the creation of competitive advantages within organizations (Penrose, 1959). Nevertheless, the generation of this attribute occurs only when the intangible assets are transformed into a unique and complicated feature of balancing by the competition (Barney, 1991). It is for this reason, that it is important to imply the existence of these impalpable elements, within the companies, of which the capacities of absorption (Camison and Fores, 2010) and the intellectual capital stand out (Bontis, 1996; Brooking, 1997; Edvinsson and Malone, 2001; Skandia, 1994).

The study of the absorption capacities was originated in macroeconomics, having as objective to know the different methods of understanding and adhering the information within the organization environment (Garzon-Castrillon, 2016). This can be identified as the basis for the creation of added value through the skills and knowledge of the people who are in the organizations, with the objective of developing products and/or services related to the company through innovation (Cohen and Levinthal, 1990). Such authors are identified as the pioneers in using the term "absorption capacities", when they emphasized the relevance of the feedback as a support of acquiring external knowledge. However, in 1980, this inference was externalized when Japanese companies surprised with a rapid growth and they were worldwide recognized as the most outstanding (Ouchi, 1985). 
In this sense, Lane, Koka, and Pathak (2016), expressed that absorption capacities are basically the way in which members of an organization understand and exploit their knowledge, this being an extremely valuable process for companies, as it can lead to the generation of intellectual capital. Likewise, Zahra and George (2002) argued that the process of developing absorption capacities is not given on its own, since the company must carry out a detection of the knowledge needs of its members and acquire such information from an external source. This with the objective of increasing the capacities of the individuals, which will allow to make improvements in processes, decrease in costs, increase their productivity, and even innovate within the functional areas of the company. Porter and Siggelkow (2008) explained that absorption capacities get stronger from the relationship among the individuals who conformed the company, by transmitting and implementing good work practices.

By going back to the emergence of the knowledge society as the origin of this new business vision, it is remarkable that an event that has been born from this ideology is the entrepreneurship (Schumpeter, 1950). This has been originated by the detection of the constant evolution of the market needs (McClelland, 1961). Hence it is here, where the variables of absorption capacities and intellectual capital emerge as the detonator of the innovation development (Subramaniam and Youndt, 2005). Nevertheless, the phenomenon of entrepreneurship has been found with a series of complications, such is the case of Mexico, where despite of being within the countries with the highest index of entrepreneurs in the world paradoxically is lacking an entrepreneurial culture (Fairlie and Woodruff, 2005).

Although, 53.2\% of the Mexican population between 18 and 64 years of age wants to start their own business (Global Entrepreneurship Monitor [GEM], 2014), the reality is that in Mexico -it is opened around 200,000 companies per year -however, $65 \%$ closes operations in two years, while only 50\% manages to survive the first year, and only $10 \%$ lasts to the tenth year (Morales, 2011). Such statistics, show that in the entrepreneurship there is an absence in the use of intangible assets, stopping the growth and survival of the companies (Barney, Ketchen, and Wright, 2011), in this case Mexicans' companies. It should be pointed out that intangible assets such as absorption capacity and intellectual capital (Cohen and Levinthal, 1989) could be tools for the organizations' development. However, it is still unclear how these variables are associated, even though both have certain similarities like their intangible nature, their strategic emphasis, the use of knowledge and their ability to generate sustained competitive advantages. This is more evident in the business incubators, where it is sought that entrepreneurs generate added value in their productive projects. The following research questions arise from such premises: How do absorption capacities and intellectual capital relate to graduated companies from business incubators in the north of Mexico?

Taking into consideration that the sample in this study is formed by entrepreneurs graduated from business incubators, the absorption capacities are understood like the way in which the individuals employ the learning (Cohen and Levinthal, 1989). From this, it can be observed that the absorption capacities in the entrepreneurs' education can be associated with the intellectual capital (Bontis, 1999). Therefore, the second research question arises: How do the absorption capacities affect the intellectual capital in companies graduated from a business incubator in the north of Mexico?

The following hypotheses arise from the research questions raised above:

$H_{1}$ : The absorptive capacities of the graduated companies from a business incubator of the Technological Institute of Sonora are positively related to the generation of intellectual capital within them.

$\mathrm{H}_{2}$ : The absorptive capacities of the graduated companies from a business incubator of the Technological Institute of Sonora influence significantly and positively on the generation of intellectual capital within them.

\section{Absorptive Capacities:-}

The absorptive capacities can be understood as the functional diversity of the organizations to acquire, assimilate, transform and exploit the knowledge, with the purpose of creating new skills that evolve according to the objectives of the company (Zahra and George, 2002).

\section{Acquisition:-}

Acquisition is the first phase of the absorptive capacities and is recognized as an organization's ability to obtain information (Lane and Lubatkin, 1998). Zahra and George (2002) argue that this phase lies in the ability to obtain relevant knowledge through external sources.

\section{Assimilation:-}

Zahra and George (2002) mention that assimilation is the stage of study and comprehension of previously acquired information, in order to become a learning process. 


\section{Transformation:-}

The transformation is the third element of the absorptive capacities and is based on the analysis and adaptation of the acquired and assimilated knowledge. It helps the organization to apply new designs in its processes or to improve the existing ones based on new information (Zahra and George, 2002).

\section{Exploitation:-}

According to Zahara and George (2002), exploitation goes beyond of applying knowledge to the needs of organizations, as it implies that the creation of elements generates value, and therefore raises their competitiveness in the market.

\section{Intellectual capital:-}

Bontis (1996) explains that intellectual capital is the transformation of knowledge and experience into valuable assets for organizations. Furthermore, it segments this asset in three different classes of capital: intellectual, structural and relational. However, the author assures that, although it is one of the most relevant assets for companies, it has been little understood and valued by most of the organizations.

\section{Human capital:-}

For Bontis (1996), human capital consists of the inventory of both implicit and explicit knowledge of the people who are part of a company. This being the genesis of the process for the generation of intellectual capital, since it is precisely of that component where the improvement strategies are detached and the basic knowledge is obtained. Subsequently, the strategies and knowledge are organized, documented and applied through the performance of the individuals that integrate the company.

\section{Structural Capital:-}

The structural capital comprises the compilation, documentation and organization of the knowledge that is derived from the human capital, through process guides, strategic actions, forms and reports that add value to the organization (Bontis, 1996).

\section{Relational Capital:-}

According to Bontis (1996), the basis of relational capital is the capacity of the organization to relate with the external environment. In this sense, this capital can be understood as the comprehension of the company towards the most influential elements, related to the market to which the economic unit is directed, considering the suppliers that contribute to the best performance of the same (Bontis, 1999).

\section{Relationship between absorptive capacities and intellectual capital:-}

Cohen and Levinthal (1990) mention that absorptive capacities measure the degree of understanding and utilization of companies in relation to information received by external sources, that is, they explain how organizations benefit from the introduction of that knowledge to the organization. Nevertheless, if the knowledge is not documented in such way that it can be understood and transmissible, this information will not achieve the strategic objectives of the organization (Edvinsson and Malone, 1999). Moreover, Murovec and Prodan (2008) suggest that the integration of new knowledge can be converted into new products, services or process, or it can help in the improvement of the existing products or services.

\section{Methodology:-}

A quantitative approach was adopted in the present research work. It was collected and analyzed numerical data concerning to the analyzed variables (Briones, 2002): absorptive capacities and intellectual capital. In addition, this is a transversal research, because it only describes the relationship and influence between the variables at any given time; likewise, this study shows a correlation because its purpose was to know the relationship between the analyzed variables (Hernández, Fernandez, and Baptista, 2010).

\section{Study Sample:-}

The analyzed population in this research is the graduated companies from a business incubator in the north of Mexico, during the years 2014, 2015 and 2016, being a total number of 370 companies. A sample of 100 subjects was established, all of which are the owners of the incubated companies. The type of sampling used was intentional selection, which is a non-probabilistic method, and it consists in selecting a representative sample of the target population in a subjective way (Casal and Mateul, 2003). 
$45 \%$ of the studied economic units are in the light industry sector, $29 \%$ in the services segment and the remaining $26 \%$ are dedicated to trade. In addition, it was found that within these companies, the activity of greatest recurrence was the preparation of food by representing $38 \%$ of the sample. Also, it is important to emphasize that $43 \%$ of the companies have one to three years of life, $30 \%$ have four to six years of operation, $14 \%$ have a survival span of eight to ten years and, finally, only $13 \%$ of the analyzed organizations have subsistence greater than 10 years.

\section{Measurement instrument:-}

The evaluation tool used to collect the data that causes the development of this research consists in two segments and has a total of 31 items.

The first segment contains 17 questions evaluating the four dimensional absorptive capabilities, (acquisition, assimilation, transformation and exploitation), suggested within the model of Zahra and George (2002). The second section comprises 14 questions based on the proposal of Subramanian and Youndt (2005), which it evaluates the intellectual capital in three suggested dimensions by authors. The questions are written in an affirmation form and are evaluated using 5 levels of the Likert scale because it is easy for the pollster to apply it and for the respondent to answer (Ospina et al., 2005).

Regarding to the validity, the analysis was carried out using the Cronbach Alfa to measure the instrument reliability. Kaplan and Saccuzzo (1982) mention that the result of this coefficient should be greater or equal to 0.7, in order to have an acceptable level of trust. Also, it was found that the used items for the evaluation of the dimensions: acquisition $(\alpha=0745)$ and transformation $(\alpha=0727)$, belonging to the absorptive capacity, are reliable because they show an alpha greater than 0.7. However, assimilation $(\alpha=0475)$ and exploitation $(\alpha=0568)$ are considered unreliable because the index remained below the recommended level. On the other hand, the reliability of the dimensions contemplated by the intellectual capital is superior to the one that is recommended. It is for this reason, we only validate the used items to carry out the evaluation of the human capital $(\alpha=0773)$, relational capital $(\alpha=$ 0881) and structural capital $(\alpha=0701)$.

\section{Results and Discussion:-}

Based on the information obtained from the statistical analysis, through the application of the measuring instrument to a sample of 100 entrepreneurs, it was found that, while the entrepreneurs acquired new knowledge, not all have communication skills. Hence, it causes that such understanding is not divulged among other members of the company. Moreover, concerning to the application of the new obtained knowledge, it was observed discrepancy in this dimension. This is because employers consider that in their organizations have the needed skills to develop this knowledge, however not everyone believes that the functions within their companies are well segmented.

On the other hand, in terms of intellectual capital it is denoted that there is human capital in the studied organizations, because the entrepreneurs estimate that their collaborators have the skills and talents needed to perform their functions within the company. Furthermore, they are largely considered to contribute with their knowledge to the growth of the organization. As far as relational capital is concerned, the results show that despite the fact that the members of the consulted enterprises have knowledge about the company's sector, there is no close relationship with the outside environment i.e. customers and suppliers, which it limits their results. Additionally, it can be observed that the majority of the entrepreneurs managed to convert knowledge into structural capital by documenting manuals or procedures; however, it is almost null the number of companies that use patents and licenses as a way to retain knowledge.

Through the proposed hypotheses, it is partially checked that not all variables analyzed are related; however, the variables that show some degree of meaningful relationship have a positive connection (See table 1).

Table 1:- Correlation of variables $(N=100)$

\begin{tabular}{|l|l|l|l|l|l|l|l|}
\hline Measure & $\mathbf{1}$ & $\mathbf{2}$ & $\mathbf{3}$ & $\mathbf{4}$ & $\mathbf{5}$ & $\mathbf{6}$ & $\mathbf{7}$ \\
\hline 1. Acquisition & - & & & & & & \\
\hline 2. Assimilation & $.464^{* *}$ & - & & & & \\
\hline 3.Transformation & $.393^{* *}$ & $.240^{* *}$ & - & & & & \\
\hline 4.Explotation & .194 & .195 & $.526^{* * *}$ & - & & & \\
\hline 5.Human capital & $.319^{* * *}$ & -.009 & $.406^{* *}$ & .190 & - & \\
\hline
\end{tabular}




\begin{tabular}{|l|l|l|l|l|l|l|l|}
\hline 6. Relational capital & $.260^{* *}$ & .002 & $.366^{* *}$ & .190 & $.811^{* *}$ & - \\
\hline 7. Structural capital & $.243^{* * * *}$ & -.046 & $.547^{* *}$ & $.266^{* *}$ & $.455^{* *}$ & $.473^{* *}$ & - \\
\hline
\end{tabular}

Note. $* * \mathrm{p}<0,01$ (two tails).

As can be seen in the results of the correlation of the variables, the acquisition and transformation dimensions, belonging to absorptive capacities, are the most related with the generation of intellectual capital within the studied companies. In addition, the connections of transformation-structural capital are the ones with the highest impact. This indicates that when the company adapts the acquired knowledge to the operations of the organization, new processes or unique systems are generated within them. In general, the transformation variable is positively related to the human capital, and relational and structural, which it indicates that the given knowledge from the trainings program of the business incubator were understood and adapted according to the needs of the participating organizations.

Also, it was found a significant and positive relationship between exploitation and structural capital. This means that those companies that applied the new acquired knowledge, they documented it and made them part of their value proposition. Nevertheless, the results indicate that the entrepreneurs did not get to apply the acquired knowledge within their organizations, which detracts value to the granted skills since the lack of execution stops the value generation in the incubated companies. Through the resulting information from this research work, it was obtained a database to assert that absorptive capacities are positively influential with the generation of intellectual capital in companies (See tables 2-4). In this sense, the results are assimilated to the suggestion of Girma and Görg (2002). They ensure that absorption capacities are really important for a company, so it could benefit from external knowledge and then turn it into human capital, by preparing employees with suitable competencies to perform the necessary positions in companies.

Table 2:- Regression analysis considering to "human capital" as dependent variable $(N=100)$

\begin{tabular}{|l|l|l|l|l|l|}
\hline Factor & $\mathbf{B}$ & $\mathbf{S E}$ & $\boldsymbol{\beta}$ & $\mathbf{t}$ & $\mathbf{p}$ \\
\hline Acquisition & 0.424 & 0.162 & 0.289 & 2.612 & 0.011 \\
\hline Assimilation & -0.412 & 0.189 & -0.229 & -2.182 & 0.032 \\
\hline Transformation & 0.486 & 0.163 & 0.345 & 2.989 & 0.004 \\
\hline Exploitation & 0.014 & 0.141 & 0.011 & 0.097 & 0.923 \\
\hline Note. $\mathrm{R}^{2}=.204$ & & & & \\
\hline
\end{tabular}

Table 3:- Regression analysis considering to "relational capital" as dependent variable $(N=100)$

\begin{tabular}{|l|l|l|l|l|l|}
\hline Factor & B & SE & B & t & p \\
\hline Acquisition & 0.319 & 0.184 & 0.199 & 1.732 & 0.087 \\
\hline Assimilation & -0.339 & 0.214 & -0.173 & -1.584 & 0.117 \\
\hline Transformation & 0.472 & 0.185 & 0.308 & 2.557 & 0.012 \\
\hline Exploitation & 0.066 & 0.16 & 0.047 & 0.415 & 0.679 \\
\hline
\end{tabular}

Note. $\mathrm{R}^{2}=.136$

Table 4:- Regression analysis considering to "structural capital" as dependent variable $(N=100)$

\begin{tabular}{|l|l|l|l|l|l|}
\hline Factor & B & SE & B & t & p \\
\hline Acquisition & 0.202 & 0.142 & 0.147 & 1.422 & 0.159 \\
\hline Assimilation & -0.44 & 0.163 & -0.268 & -2.702 & 0.008 \\
\hline Transformation & 0.674 & 0.138 & 0.52 & 4.89 & 0.00 \\
\hline Exploitation & 0.083 & 0.12 & 0.07 & 0.698 & 0.487 \\
\hline
\end{tabular}

Note. $\mathrm{R}^{2}=.323$

\section{Conclusion:-}

Based on the resulting data, it is shown that between the absorptive capacities and the intellectual capital of the graduated companies from the incubator, there is a partial relationship since not all variables relate to each other. However, there is a positive influence between them, although not all crosses were significant.

In the case of the analyzed subjects in this study, it is denoted that they sense respect and closeness by the consultants of the training program, granted by the business incubator $(M=4.36)$. Therefore, as part of the 
acquisition capacity, it influences in a significant and positive way the generation of capital: human $(r=.319 ; p=$ $.01)$, relational $(r=.260 ; p=.01)$ and structural $(r=234 ; p=.01)$. Due to all of the above, it is confirmed that the relationship of mutual trust and respect between the external source of knowledge and the company contributes to the generation of intangible assets, which Subramaniam and Youndt (2005) consider the basis of success for any organization.

Likewise, it is corroborated that the source of information is influential on the generation of intellectual capital. In addition, it is even more relevant the transformation, meaning in the way in which the company adapts the acquired knowledge to the conditions of its organization, as well as its environment (Todorova and Durisin, 2007). If the entrepreneur has the ability to appropriate the information and convert it in improvements to their needs, it increases the chances that their company will survive, as it confirms that it may be able to adapt to market changes (Zahra and George, 2002).

In addition, it was found that, although the entrepreneurs understood the information provided and they transformed it, they did not execute significant changes in their company. As a result, they did not fully exploit the new acquired knowledge which directly impacts on the almost null generation of structural capital. The above suggests that the beneficiary of the training programs requires further monitoring and accompaniment to the transfer of knowledge.

Although the hypothesis was partially tested, it is very important to emphasize that by finding a significant relationship and influence only between some variables belonging to absorptive capacities and intellectual capital, (acquisition-human, relationship and structural capital), (transformation-human, relationship and structural capital) (exploitation-structural capital), we can establish a precedent on factors that affect the creation of intangible assets in the Sonoran microenterprises.

The results obtained are the basis for future research related to the research topics, so it is recommended to improve or delete items in the evaluation instrument to increase the reliability degree. Also, it is important to analyze other intangible assets that impact in the value of the organization. Finally, it is also suggested to extend the sample in order to achieve a greater degree of construct validity, as it is not included in this research, due to the sample number used.

\section{Acknowledgement:-}

This work was supported in part by Instituto Tecnológico de Sonora through the "Program for the Support and Development of Research Projects" (PROFAPI, by its Spanish acronym).

\section{References:-}

1. Barney, J. B. (1991). Firm resources and sustained competitive advantage. Journal of Management. 1(17): 99120.

2. Barney, J. B., Ketchen, D. J., and Wright, M. (2011). The future of resource-based theory revitalization or decline? Journal of Management. 37(5): 1299-1315.

3. Bontis, N. (1996). Intellectual capital: an exploratory study that develops measures and models. Management Decision. 36(2): 67-76.

4. Bontis, N. (1999). Managing Organizational Knowledge by Diagnosing Intellectual Capital: Framing and advancing the state of the field. International Journal of Technology. 18(5): 433-462.

5. Briones, G. (2002). Metodología de la investigación cuantitativa en las ciencias sociales. Bogotá, Colombia. Instituto colombiano para el fomento de la educación superior.

6. Brooking, A. (1997). Capital Intelectual. Barcelona, España. Editorial Paidos Ibérica.

7. Camisón, C., and Forés, B. (2010). Knowledge absorptive capacity: New insights for its conceptualization. Journal of Business Research. (63): 707-715.

8. Casal, J., and Mateu E. (2003). Tipos de Muestreo Revista de Epidemiología y Medicina Preventiva. Barcelona. Universidad Autónoma de Barcelona.

9. Cohen, W., and Levinthal, D. (1989). Innovation and learning: the two faces of R\&D. Economic Journal. 99(397): 569-596.

10. Cohen, W., and Levinthal, D. (1990). Absorptive capacity: a new perspective on learning and innovation. Administrative Science Quarterly. 35: 128-152. 
11. Drucker, P. (1969). The age of discontinuity: Guidelines to our changing society. Nueva York. U.S. Harper \& Row.

12. Edvinsson, L., and Malone, M. S. (2001). El capital intelectual, cómo identificar y calcular el valor de los recursos intangibles de su empresa. México. Gestión 2000.

13. Fairlie, R. W., and Woodruff, C. (2007). Mexican entrepreneurship: A comparison of self-employment in Mexico and the United States. En G. J. (Ed.). Mexican immigration to the United States (pp. 123-158). Chicago. University of Chicago Press.

14. Garzón-Castrillón, M. A. (2016). Capacidad dinámica de absorción. Estudio de caso Orinoquia. Revista Orinoquia. 20(1): 97-118.

15. Girma, S. y Görg, H. (2002). Foreign direct investment, spillovers and absorptive capacity: Evidence from quantile regressions. Research paper/Leverhulme Centre for Research on Globalisation and Economic Policy, No. 2002, 14.

16. R. Hernández, C. Fernández and M. Baptista. (2010). Metodología de la investigación. México. Mc Graw Hill.

17. Kaplan, R. S., and David, N. (1992). The Balanced Scorecard: Measures that Drive Performance. The Balanced Scorecard: Measures that Drive Performance. 70(1): 71-79.

18. Lane, P., and Lubatkin, M. (1998). Relative Absorptive Capacity and Interorganizational Learning. Strategic Management Journal. 19(5): 111-125.

19. Lane, P. J., Koka, B. R., and Pathak, S. (2006). The reification of absorptive capacity: a critical review and rejuvenation of the construct. Academy of Management Review. 31: 833-863.

20. Machlup, F. (1962). The production and distribution of knowledge in the United States. New Jersey. U.S. Princeton University Press.

21. McClelland, D. C. (1961). The achieving society. Princeton. New Jersey. D. Van Norstrand Company.

22. Morales, I. (2011). Las Pymes en México; entre la creación fallida y la destrucción creadora. Economía informa. 366: 39-48.

23. Murovec, N., and Prodan, I. (2009). Absorptive Capacity, Its Determinants, and Influence on Innovation Output: Cross-Cultural Validation of the Structural Model. Technovation. 29: 859-872.

24. Ospina, B., Sandoval, J., Aristizábal, C., and Ramírez M. (2005). La escala de Likert en la valoración de los conocimientos y las actitudes de los profesionales de enfermería en el cuidado de la salud. Invest Educ Enferm. 23(1): 14-29.

25. Ouchi, W. G. (1985). Theory Z how American Business can meet the Japanese. Barcelona. Orbis.

26. Penrose, E. (1959). The theory of growth of the firm. New York. U.S. New York University Press.

27. Porter, M., and Siggelkow, N. (2008). Contextually within Activity Systems and Sustainability of Competitive Advantage. Acad manage perspect. 22(2): 34-56.

28. Schumpeter, J. (1950). The process of creative destruction, capitalism, socialism and democracy. New York. Harper \& Row.

29. Skandia. (1994). Visualizing intellectual capital at Skandia. Supplement to Skandia's 1994 Anual Report.

30. Singer, S., Amorós J., and Moska D. (2014). Global Entrepreneurship Monitor, 2014 Global Report. Global Entrepreneurship Research Association.

31. Subramaniam, M., and Youndt, M. A. (2005). The influence of intellectual capital on the types of innovative capabilities. Academy of Management Journal. 48: 450-463.

32. Todorova, G., and Durisin, B. (2007). Absorptive Capacity: Valuing a Reconceptualization. Academy Of Management Review. 32(3): 774-786.

33. Zahra, S. A., and George, G. (2002). Absorptive capacity: A review, reconceptualization and extension. Academy of Management Review. 27(2): 185-203. 